\title{
FIRST RECORD OF Brachycerus sinuatus Olivier, 1807 (COLEOPTERA: CURCULIONIDAE) IN SERBIA
}

\author{
Snežana B. Pešić ${ }^{*}$, Milan Đurić², Bojana Nadaždin ${ }^{2}$, Ivan Tot ${ }^{2}$ \\ ${ }^{1}$ University of Kragujevac, Faculty of Science, Department of Biology and Ecology, \\ Radoja Domanovića 12, 34000 Kragujevac, Serbia \\ ${ }^{2}$ Association for Sustainable Development and Habitat Protection in Serbia "HabiProt" \\ Cankareva 9/3, 21000 Novi Sad, Serbia \\ *Corresponding author; E-mail: snezana.pesic@ pmf.kg.ac.rs
}

(Received April 20, 2020; Accepted May 05, 2020)

\begin{abstract}
The unusually looking weevil species Brachycerus sinuatus Olivier, 1807 was collected in April 2019 in the vicinity of Preševo (southern Serbia). It is the first finding of this species for Serbia. By this data, its area of distribution is substantially extended westwards. Very precise data about the locality where it was found in contributing to the knowledge of its ecology.
\end{abstract}

Keywords: weevil, new record, southern Serbia, Pčinja District, Preševo.

Brachycerus Olivier, 1790 is quite unusuall looking weevil genus. These robust, 6-18 mm long (АНГЕЛОВ, 1978), black flightless beetles, with dorsally flattened rostrum, have got very furrowed, embossed relief structure on the surface and reminiscent of unordinary armored warriors, resembling aliens. Their short, compact antennas are not of elbow type (as found in most weevils) and consist of only nine segments. The elytra are fused and roughly sculptured. This genus belongs to the subfamily Brachycerinae that comprises six very different tribes. In the Palearctic region, one of these six tribes, Brachycerini, is represented by only one genus, Brachycerus (ALONSO-ZARAZAGA and LYAL, 1999). This genus encompasses approximately 300 species, mostly in Ethiopian zoogeographical region, much less in the Palaearctic (49 species and two subspecies), primarily in North Africa (АНГЕлов, 1978; AlONSO-ZARAZAGA et al., 2017).

This genus was in the scientific focus more than a hundred years ago (BEDEL, 1874a, 1874b; ReY, 1894; Vitale, 1903; Bovie, 1909; ESCALERA, 1918; ZuMPT, 1937a, 1937b; PARDO AlCAIDE, 1945; SOLARI, 1949; HAAF, 1957a, 1957b, 1958), but a century later interest for it has been refreshed (ARZANOV, 2005, 2011; ARZANOV and FRIEDMAN, 2012; COLONNELLI, 2014; AlZIAR, 2016; FrIEDMAN, 2017; Elmetwaly and HAMED, 2019; VerdugO and Le PEN, 2020). It is a little surprising that so robust and unusually looking beetles remains mysterious to the science, and even new species have been recently described, such as armeniacus, kubanicus, mlokosevitschi and turkmenicus from the Caucasus and surrounding countries (ARZANOV, 2005), hermoniacus, groneri and wizeni from Israel (FRIEDMAN and SAGIV, 2010), skopyi from Syria (ARZANOV, 2011), anatolicus from Turkey (ARZANOV and FRIEDMAN, 2012), makrisi from Cyprus (AlZIAR, 2016) and socotranus from Socotra (FRIEDMAN, 2017). 
Brachycerus sinuatus, together with 18 similar species belongs to the aegyptiacus group (FRIEDMAN and SAGIV, 2010). All of them are oval and with rounded elytra and distinct elytral ridges neither of which stands out and all are subdivided into irregular and uneven tubercles.

During the wider collecting entomological expedition organized by "HabiProt" in the south of Serbia in spring 2019, on April $25^{\text {th }} 2019$ two male specimens of Brachycerus sinuatus Olivier, 1807 were collected. After genitalia preparing, one specimen was determined with a help of printed (АНГЕЛОв, 1978) and digital (SKUнROVЕС et al. 2013) keys, and confirmed by specialist, Dr Friedman A.-L.-L. from Israel. The prepared specimen is stored in S. Pešić's weevils collection, at the Faculty of Science in Kragujevac. The other specimen (undetermined by sex) from the same location is a part of HabiProt entomological collection.

Taxonomically, B. sinuatus belongs to family Curculionidae, subfamily Brachycerinae Billberg, 1820, tribe Brachycerini Billberg, 1820, subtribe Brachycerina Billberg, 1820, genus Brachycerus Olivier, 1789 (AlONSO-ZARAZAGA et al., 2017).

Synonyms: besseri Krynicki, 1832, and insularis Desbrochers des Loges, 1871.

- Collecting date: April $25^{\text {th }} 2019$.

- Locality data: in the Pčinja District of southern Serbia, close to a small stream (Fig. 1A), between the Miratovac and Trnava villages (Fig. 1B), on the territory of Preševo, near the Serbia-North Macedonia border (Fig. 1C).

- Geographic coordinates: 42 $16^{\prime} 20^{\prime \prime} \mathrm{N}, 2^{\circ} 39^{\prime} 1,6^{\prime \prime} \mathrm{E}$, altitude approximately $550 \mathrm{~m}$.

- Habitat: rocky, warm habitat with strong submediterranean influence from the south, covered with limited vegetation of mosaic composed from small fragments of forests with Quercus pubescens and dry pastures (Fig. 1A), with flowering Muscari sp.
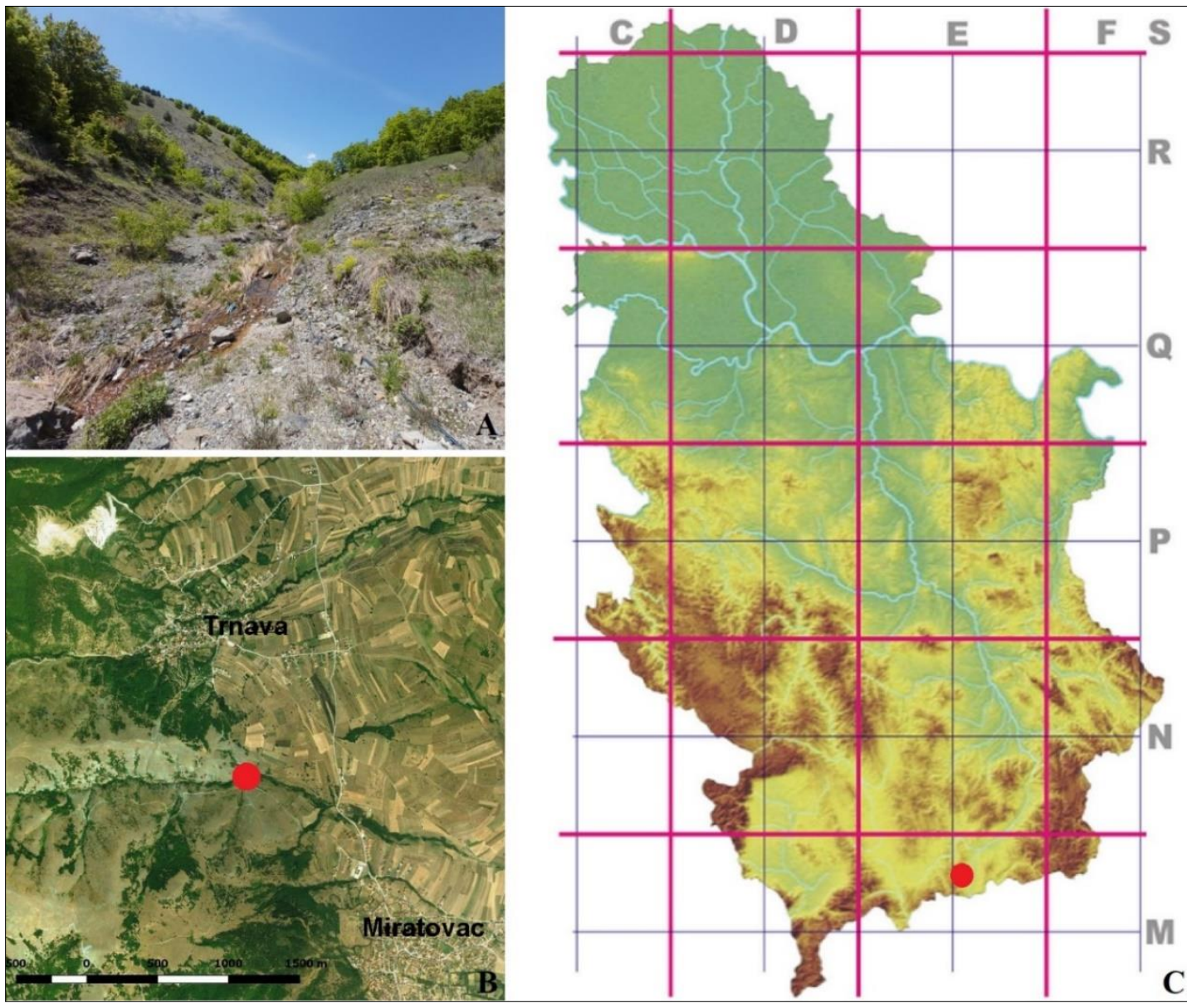

Figure 1. Brachycerus sinuatus finding place: A - habitat, photo M. Vujić 2019;

$\mathrm{B}$ - Google map of the explored place; $\mathrm{C}$ - position of finding place in UTM map of Serbia. 
One collected specimen is male, $16 \mathrm{~mm}$ long including the rostrum, the other one is $1 \mathrm{~mm}$ shorter. Literally, entire surface of their bodies is covered with round punctures of variable size and density. The anterior edge of the pronotum in the middle is clearly elongated forward, towards the forehead. Two strong ridges start from there, enclosing the median grove on the pronotum that starts there and extends to the pronotum posterior edge, i.e. distinctly is present in its entire length. Median grove is slightly shallower in the middle, and wider on the end.

Thanks to the small scales, dust and dirtiness collected in the groves among the tubercles, it looks like beetles possess zig-zag elytral ridges. The first ridges, near the elytral suture, together have a viper-like pattern (Fig. 2 A, C).
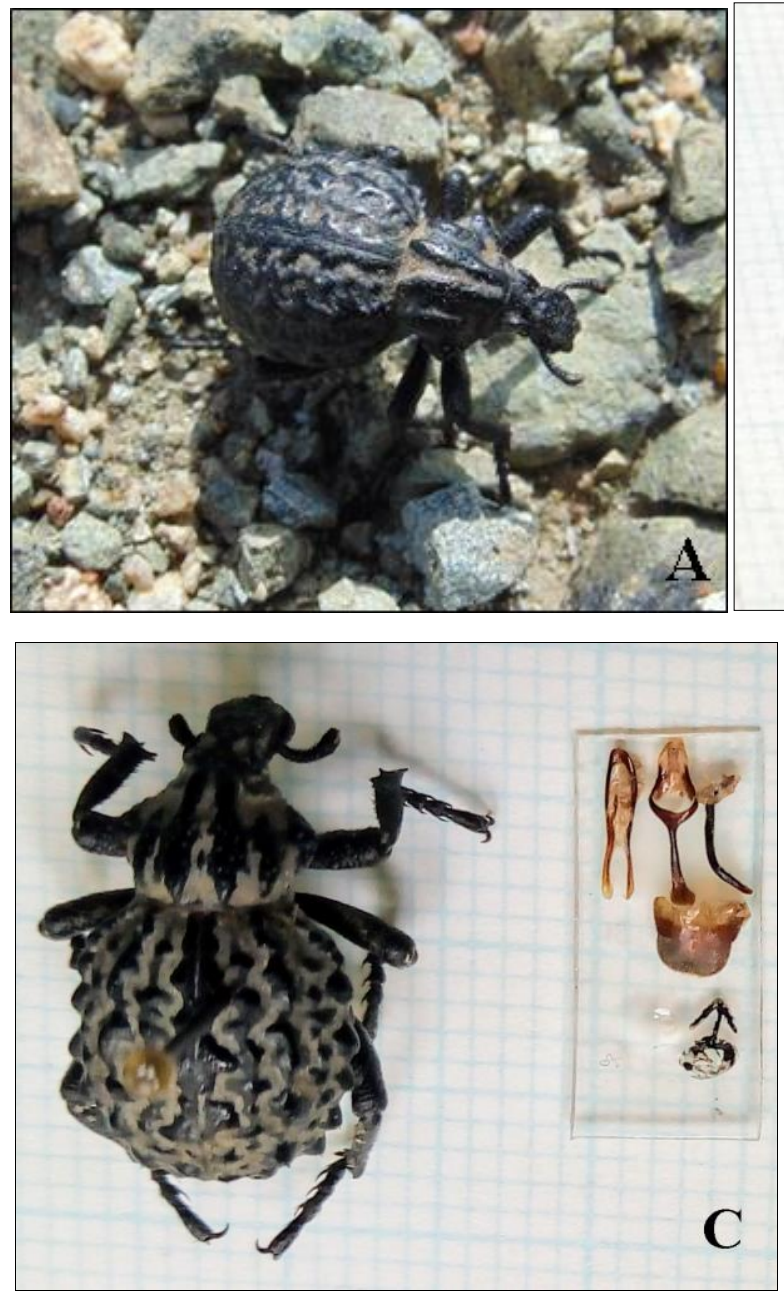

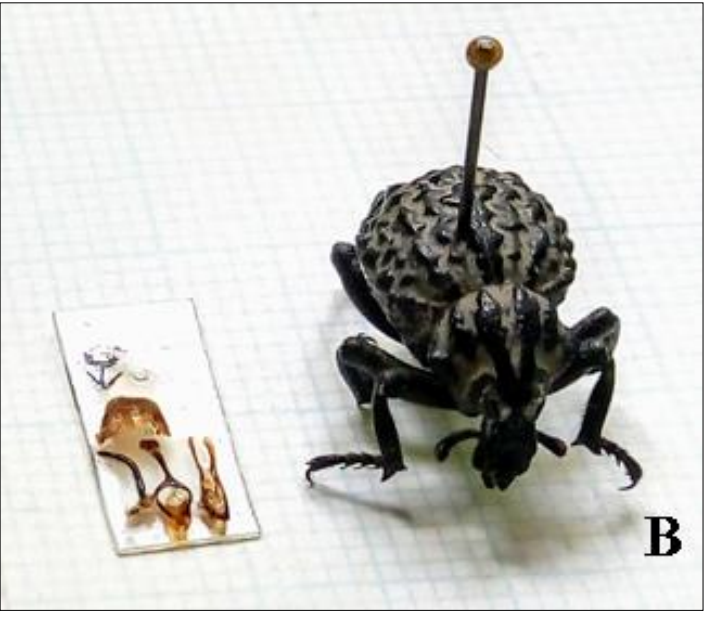

B
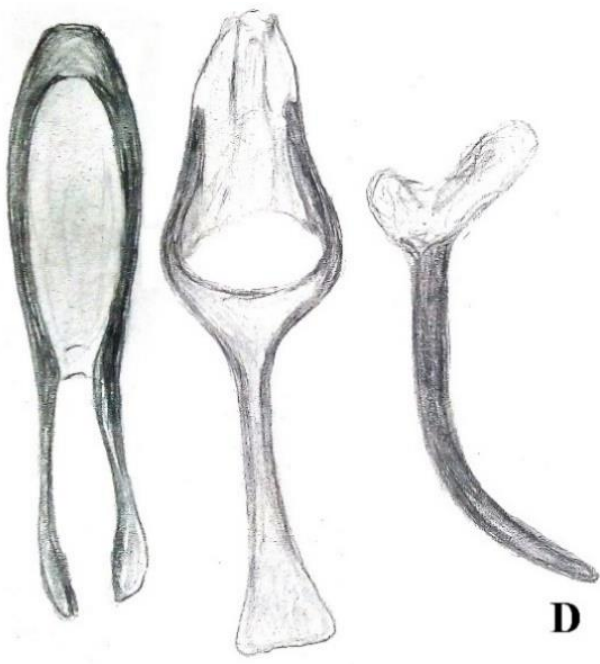

Figure 2. Brachycerus sinuatus: A - in situ, photo M. Đurić 2019;

B - afore, from the collection, photo S. Pešić 2020; C - dorsal view, photo S. Pešić 2020; $\mathrm{D}$ - aedeagus, tegmen and spiculum ventrale, $\mathrm{S}$. Pešić.

Ecological note: Muscari sp. is registered as a B. sinuatus host plant in Bulgaria (АНГЕлов, 1978), while in the Rostov region in Russia that role is taken by Bellevalia sarmatica (Gregori) and Hyacinthella pallasiana (Stev.) (ARZANOv, 2005). All three species are from fam. Asparagaceae.

Distribution: According to SKUHROVEC et al. (2013) and the newest Palaearctic weevils catalogue (ALONSO-ZARAZAGA et al., 2017), B. sinuatus lives in Sicily, south-eastern Europe, and Middle East, or more precisely, by countries in Europe: in Bulgaria, Greece (BAHR et al., 2020), Italy (Sicilia), North Macedonia, Romania, Ukraine and South European territory of Russia; in Asia: in Azerbaijan, Armenia, Cyprus and Turkey.

Its potential IUCN status is not evaluated. 


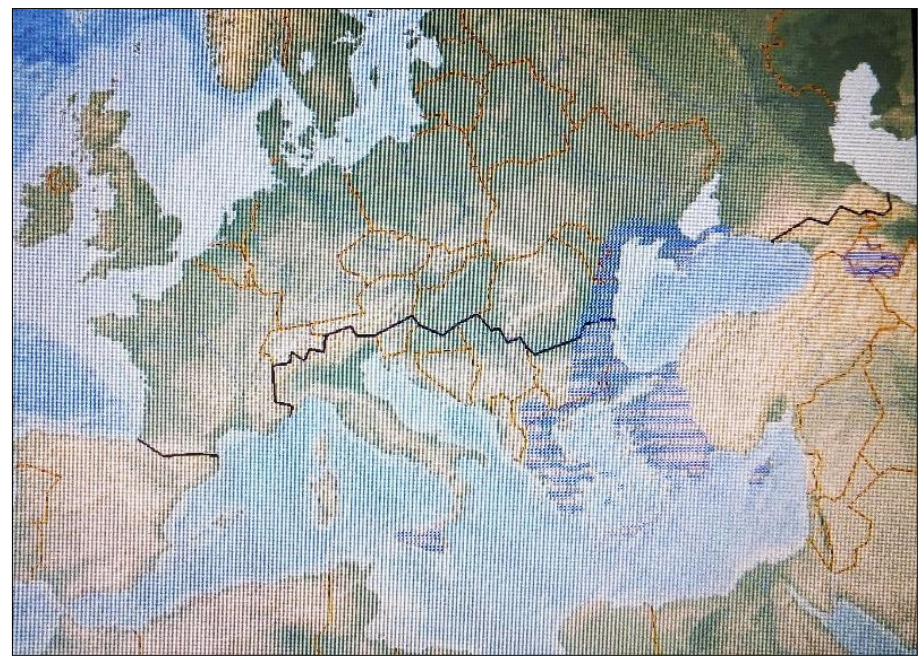

Fig. 3. Distribution of Brachycerus sinuatus Olivier, 1807 - hatched blue (from SKUHROVEC et al., 2013).

The finding reported here is already included in "Alciphron" - Online Database for Collecting Data on Insects in Serbia (HABIPROT, 2014-2020). The same database contains two findings of closely related species B. foveicollis Gyll. in Serbia, but those records are not yet confirmed.

\section{Acknowledgments}

This result comes from the wider research project realized by the Association for $\mathrm{Su}$ stainable Development and Habitat Protection in Serbia "HabiProt". We are grateful to Dr Friedman A.-L.-L. from Israel for species identification confirmation.

\section{References:}

[1] Alonso-Zarazaga, M.A., Barrios, H., Borovec, R., Bouchard, P., Caldara, R., ColonNelli, E., GÜltekin, L., Hlaváč, P., Korotyaev, B., Lyal, C.H.C., MaChado, A., MereGAlli, M., Pierotti, H., Ren, L., SÁNCHEZ-Ruíz, M., SFORZi, A., SilfVERBERG, H., SKUHROVEC, J., TRÝZNA, M., VeláZqueZ DE CASTRO, A.J., YunAKOV, N.N. (2017): Cooperative Catalogue of Palaearctic Coleoptera Curculionoidea. Monografías electrónicas S.E.A. 8: 729 pp.

[2] Alonso-Zarazaga, M. A., Lyal, C.H.C. (1999): A world catalogue of families and genera of Curculionoidea (Insecta: Coleoptera) (Excepting Scolytidae and Platypodidae). Entomopraxis; Barcelona: 315 pp.

[3] AlzIAR, G. (2016): Brachycerus makrisi n. sp. (Coleoptera, Curculionoidea, Brachyceridae) de Chypre; mise au point sur les espèces de Brachycerus de l'île. Biocosme Mesogéen 33 (1-2): 1-10.

[4] АнгеЛОВ, П. (1978): Фауна на България 7 -Coleoptera, Curculionidae II част: Brachyderinae, Brachycerinae, Tanymecinae, Cleoninae, Curculioninae, Myorrhininae: 104-109 стр.

[5] ARZANov, U..G. (2005): Obzor dolgonosikov roda Brachycerus Olivier (Coleoptera: Brachyceridae) evropejskoj časti Rossii, Kavkaza i sopredel'nyh stran. Kavkazskij Ėntomologičeskij Bûlleten' 1 (1): 65-80.

[6] ARZAnov, Û.G. (2011): Novyj vid roda Brachycerus Billberg, 1820 (Coleoptera: Brachyceridae) iz Sirii. Kavkazskij Ėntomologičeskij Bûlleten' 7 (1): 57-59.

[7] ARZANOv, Û.G., FrIEDMAN, A.-L.-L. (2012): New species of Brachycerus Olivier (Coleoptera: Brachyceridae) from Turkey. Russian Entomological Journal 21 (1): 53-55. 
[8] BAHR, F., Winkelmann, H., BAYER, C. (2020): Catalogue of the Curculionoidea (Coleoptera) of Greece: Full Catalogue http://curci-gr.site.at/gesamt/gesamt.html Accessed 02 June 2020.

[9] BEDEL, L. (1874a): Révision des brachycérides du bassin de la Méditérranée. Annales de la Société Entomologique de France (5) 4 (1): 119-144.

[10] BEDEL, L. (1874b): Révision des brachycérides du bassin de la Méditérranée. Annales de la Société Entomologique de France (5) 4 (2): 145-212.

[11] BovIE, A. (1909): Coleoptera. Fam. Curculionidae. Subfam. Brachycerinae. In: Wytsman, P.A. (ed.): Genera Insectorum 99: 1-38, 3 pls.

[12] COLONNELli, E. (2014): Apionidae, Nanophyidae, Brachyceridae and Curculionidae except Scolytinae (Coleoptera) from Socotra Island. Acta Entomologica Musei Nationalis Pragae 54 (supplementum): 295-422.

[13] Elmetwaly, N.E., HAMED, F.Z. (2019): Review of Subfamily Brachycerinae (Coleoptera: Brachyceridae) in Egypt. Egyptian Academic Journal of Biological Sciences A. Entomology 12 (2): 139-149. doi: 10.21608/eajbsa.2019.43053

[14] ESCALERA, M.M. DE LA (1918): Una especie nueva de Brachycerus Ol. de España (Col. Curculionidae). Boletín de la Real Sociedad Española de Historia Natural 18 (9): 415-416.

[15] Friedman, A.-L.-L., SAGIV, A. (2010): Review of the genus Brachycerus Olivier in Israel (Coleoptera: Curculionoidea: Brachyceridae: Brachycerinae). Israel Journal of Entomology 40: 25-70.

[16] FRIEDMAN, A.-L.-L. (2017): A new species of Brachycerus from Socotra Island (Coleoptera: Curculionoidea: Brachyceridae). Acta Entomologica Musei Nationalis Pragae, 57 (supplementum): 173-182. doi: 10.1515/aemnp-2017-0117

[17] HAAF, E. (1957a): Revision der äthiopischen und madagassischen Arten der Gattung Brachycerus Ol. (Col. Curc.) (Mit 70 Textabbildungen). Entomologische Arbeiten aus dem Museum G. Frey 8: 1-274.

[18] HAAF, E. (1957b): Revision der äthiopischen und madagassischen Arten der Gattung Brachycerus Ol. (Col. Curc.). (Mit 70 Textabbildungen) (Fortsetzung). Entomologische Arbeiten aus dem Museum G. Frey 8: 343-559.

[19] HAAF, E. (1958): Neue äthiopische Brachycerus-Arten und eine neue Gattung der Subfamilie Brachycerinae (Col. Curc.). Entomologiche Arbeiten aus dem Museum G. Frey 9: 220-228.

[20] HABIPROT (2014-2020): Alciphron - baza podataka o insektima Srbije, http://www.alciphron.habiprot.org.rs Accessed 02 June 2020.

[21] PARdo Alcaide, A., (1945): Analectas entomológicas, IV. Los Brachycerus Ol. hispano-marroquíes. Graellsia 3: 63-70.

[22] REY, C. (1894): Remarques en passant. Famille des Curculionides (Suite). Tribu des Brachycérides. L'Échange, Révue Linnéenne 10 (113): 63-64.

[23] Skuhrovec, J., Caldara, R., Stejskal, R., Bahr, F., Trnka, F., GosiK, R. (2013): Digital-Weevil-Determination for Curculionoidea of West Palaearctic. Brachycerinae (Brachycerini, Erirhinini \& Tanysphyrini). - SNUDEBILLER: Studies on taxonomy, biology and ecology of Curculionoidea, Curculio-Institute: Mönchengladbach 14, 215: 17 pp.

[24] SOLARI, F. (1949): Brachycerus Zaninii n. sp. (Coleoptera Curculionidae). Bollettino della Società Entomologica Italiana 79: 94-95.

[25] Verdugo, A., Le PeN, T. (2020): Brachycerus rotundicollis Escalera 1918 en Portugal (Coleoptera: Curculionidae: Brachycerinae). Revista gaditana de Entomología XI: 33-37.

[26] Vitale, F. (1903): Tavola sinottica delle specie siciliane del genere Brachycerus Oliv. Rivista Italiana di Scienze Naturali 23: 2-5.

[27] ZuMPT, F. (1937a): Curculioniden-Studien XXVII. Revision der paläarktischen BrachycerusArten. Entomologische Blätter 33 (5): 348-374. 
[28] ZUMPT, F. (1937b): Curculioniden-Studien XXVII. Revision der paläarktischen BrachycerusArten. (Schluß). Entomologische Blätter 33 (6): 385-426. 